\title{
Runaway Girls and Maslow's Hierarchy of Needs: A Qualitative Interpretative Meta-Synthesis
}

\author{
Marcus Crawford \\ Department of Social Work Education, California State University, Fresno, USA \\ Email: marcuscrawford@csufresno.edu
}

How to cite this paper: Crawford, M. (2021). Runaway Girls and Maslow's Hierarchy of Needs: A Qualitative Interpretative Meta-Synthesis. Open Journal of Social Sciences, 9, 254270.

https://doi.org/10.4236/jss.2021.99019

Received: August 12, 2021

Accepted: September 11, 2021

Published: September 14, 2021

Copyright ( 2021 by author(s) and Scientific Research Publishing Inc. This work is licensed under the Creative Commons Attribution International License (CC BY 4.0).

http://creativecommons.org/licenses/by/4.0/

\section{(c) (i) Open Access}

\begin{abstract}
Runaway youth are at heightened risk for violence, substance use, suicide, and other high risk concerns. Qualitative studies have examined youth choices to leave home, involvement living on the streets, and lived experiences as stigmatized youth; however, findings from these various studies have never been analyzed together into a single synthesis of information. The purpose of this article is to synthesize the qualitative data using Qualitative Interpretative Meta-Synthesis. The researcher completed a systematic search to locate studies focused on girls who were or had been runaways, extracting themes from 10 articles to create new overarching themes that encompassed each of the articles. Results showed six new overarching themes: power/control, stigma, physical needs, safety, belonging, and acceptance. The themes of physical needs, safety, belonging, and acceptance are discussed using Maslow's hierarchy of needs paradigm. Together, the themes are constructed to discuss how helping professionals can be better prepared to help meet the myriad needs of runaway girls by utilizing the hierarchy of needs presented by Maslow. This research article provides a unique insight into working with a vulnerable population by weaving together the experiences and words of the individuals whose real-life narratives have shaped the discussion.
\end{abstract}

\section{Keywords}

Runaway, Maslow, Helping Professionals, At-Risk Youth

\section{Introduction}

Helping professionals are often involved in the lives of young people who have run away from home (Kurtz, Lindsey, Jarvis, \& Nackrud, 2000; Peled \& Komem, 2020). In looking for research to inform practice, one finds that numerous qua- 
litative studies have examined runaway youth and their choices to leave home, their involvement living on the streets, and their lived experiences as stigmatized youth. Findings from these various qualitative studies, however, have never been synthesized and analyzed together. A Qualitative Interpretative Meta-Synthesis (QIMS) accomplishes this. By synthesizing data from multiple sources, a broader, deeper, and richer understanding of the phenomenon is achieved.

\section{Literature Review}

Runaway youth represent a significant social problem in the United States with some estimating that as many as 1.5 million adolescents are runaways (NCHE, 2020). Youth run from home for myriad reasons including to escape physical or sexual abuse (Lin, 2012; Meltzer, Ford, Bebbington, \& Vostanis, 2012; Thompson, Bender, Lewis, \& Watkins, 2008). Other factors contributing to the decision to run away have included family disagreements (Whitbeck, Hoyt, \& Ackley, 1997), substance use (Nebbitt, House, Thomspon, \& Pollio, 2006), and domestic violence (Whitbeck, Hoyt, \& Bao, 2000). A multitude of increased risks exists for youth who runaway including physical violence (Hong, Espelage, \& Kral, 2011; Kidd \& Carroll, 2007), sexual victimization and violence (Cochran, Stewart, Ginzler, \& Cauce, 2002; Tyler, Whitbeck, Hoyt, \& Cauce, 2004), criminal activity (Hyde, 2005), and sexually transmitted infections including HIV (Haas et al., 2011; Unger et al., 1998). These risks are higher for girls who run away than for boys (Fasulo, Cross, Mosely, \& Leavey, 2002; Moskowitz, Stein, \& Lightfoot, 2013; Walls, Potter, \& Van Leeuwen, 2009).

Of considerable concern are the negative effects on the health of a young person after choosing to run away. Risk for self harm increases (Tyler, Whitbeck, Hoyt, \& Johnson, 2003) as do suicide attempts and death by suicides (Meltzer, Ford, Bebbington, \& Vostanis, 2012; Walls et al., 2009). Roy and colleagues (2014) found that runaway youth were 11 times more likely to die than youth who did not run away. Many of the interventions aimed at youth homelessness and runaways target basic needs like shelter, safety, and sustenance (Mendez \& Randle, 2021; Pierce, Grady, \& Holtzen, 2018; Woods, 2018), recognizing that these needs are paramount for surival (Maslow, 1943, 1954).

The study of runaway girls and their experiences, then, is important to helping professionals who assist this population. Understanding their experiences informs the profession and builds a body of evidence that advances practices in positive and affirmative ways. By using Maslow's Hierarchy of Needs to inform the analysis, the study seeks to answer the following question: How do the experiences of runaway girls inform helping professionals in assisting this population?

\section{Methods}

Qualitative Interpretive Meta-Synthesis (QIMS) is an emerging methodology in the field of qualitative social work research that utilizes a synergistic process to 
synthesize data from multiple qualitative studies in order to create a broader understanding of a topic. As such, only a handful of published articles are available utilizing this technique (e.g., Aguirre \& Bolton 2013; Bowers 2013; Frank \& Aguirre 2013; Maleku \& Aguirre 2014; Nordberg, Crawford, Praetorius, \& Hatcher, 2016; Robinson, Maxwell, \& Rogers, 2020). This study followed the outline proposed by Aguirre and Bolton (2014) where they provided a detailed process of the development of the QIMS approach.

For the QIMS, this researcher conducted analysis of the available qualitative research on runaway girls. The researcher completed a systematic search to locate research that focused on girls who were or had been runaways in their adolescence. For the searches, the researcher used Google Scholar, Social Work Abstracts, and Criminal Justice Abstracts. Search terms included in the search "female" AND "foster" OR "offender." Additionally, the phrase "runaway youth" was added to narrow the search to articles about runaways. For a QIMS, searches should be limited to qualitative articles (Aguirre \& Bolton, 2014). As such, the researcher looked for one of the following terms: qualitative, phenomenal, content analysis, narrative, grounded theory, or thematic analysis. Screening criteria comprised the following: 1) written in English; 2) published in a peer-reviewed journal; 3) utilized qualitative methodologies or mixed methods approaches; 4) contained quotations from the participants; 5) and sampled individuals who identified as female who were, or had been previously, runaways.

Initial searches in yielded 363 articles for possible inclusion in the QIMS. The researcher screened titles and abstracts and eliminated 313 articles, leaving 50 for possible inclusion. After reading the remaining articles, the researcher excluded 35. The most common reason for elimination was a quantitative methodology that was not apparent with the first review. Following a thorough review of the remaining 15 articles, the researcher identified additional flaws in five (one for each of the following: not using direct quotations, not focusing on the run away experience, creating quantitative results from the data, focus on homeless youth who had not necessarily run away, and not separating data by gender in results), leaving a total of 10 articles that met the inclusion criteria for the QIMS. The Quorum chart provides a step-by-step analysis of the process (see Figure 1).

These 10 articles represented eight studies that used a variety of qualitative approaches including ethnography, case study, narrative analysis, and phenomenology. In total, the studies sampled 122 individuals. For studies that included both males and females, the researcher examined only the results from the females for the synthesis. Studies were global, coming from the United States, Israel, Australia, and Canada. Age and available demographic information are included in Table 1.

Extraction of the themes and subthemes (if available) from the articles left the original themes intact (see Table 2). Intact themes are important because this maintains the integrity of the original research and allows comparison across the studies (Aguirre \& Bolton, 2014). Forty-three themes were pulled from the 10 
Table 1. Characteristics of studies included in the sample.

\begin{tabular}{|c|c|c|c|c|c|}
\hline Author (Date) & Title & $\begin{array}{l}\text { Qualitative } \\
\text { Method }\end{array}$ & Sample $(N)$ & $\begin{array}{c}\text { Location, of } \\
\text { interviews, } \\
\text { Age range, race }\end{array}$ & $\begin{array}{c}\text { Recruitment city, } \\
\text { state, year }\end{array}$ \\
\hline $\begin{array}{l}\text { Berman, Alvarez } \\
\text { Mulcahy, Forchuck, } \\
\text { Edmunds, Haldenby, } \\
\text { \& Lopez (2009) }\end{array}$ & $\begin{array}{l}\text { Uprooted and displaced: } \\
\text { A critical narrative } \\
\text { study of homeless, } \\
\text { Aboriginal, and } \\
\text { newcomer } \\
\text { girls in Canada }\end{array}$ & $\begin{array}{l}\text { Narrative } \\
\text { Interviews }\end{array}$ & 19 girls and women & $\begin{array}{l}\text { Interview locations } \\
\text { not provided, } \\
14 \text { to } 19 \text { years old, } \\
6 \text { Aboriginal, } \\
6 \text { homeless, } \\
7 \text { newcomer }\end{array}$ & $\begin{array}{c}\text { Southwest } \\
\text { Ontario Canada, } \\
\text { dates not given }\end{array}$ \\
\hline $\begin{array}{l}\text { Maassen, Pooley, } \\
\text { \& Taylor (2013) }\end{array}$ & $\begin{array}{l}\text { "You get forced to live } \\
\text { with randoms... and that } \\
\text { makes you stronger as } \\
\text { a person": Homeless } \\
\text { Western Australian } \\
\text { teenagers' perspectives } \\
\text { on their experiences } \\
\text { of residing in crisis } \\
\text { accommodation }\end{array}$ & $\begin{array}{l}\text { Semi-structured } \\
\text { Interviews, } \\
\text { Interpretative } \\
\text { phenomenology }\end{array}$ & $\begin{array}{c}5 \text { girls, } 3 \text { boys } \\
\text { (Use if broken } \\
\text { down by male and } \\
\text { female experience) }\end{array}$ & $\begin{array}{l}16 \text { to } 18 \text { years old, } \\
4 \text { Caucasian, } \\
1 \text { Aboriginal, } \\
2 \text { African, } 1 \text { Asian }\end{array}$ & Perth, Australia \\
\hline MacDonald (2013) & $\begin{array}{l}\text { The paradox of being } \\
\text { young and homeless: } \\
\text { Resiliency in the } \\
\text { face of constraints }\end{array}$ & Ethnography & $\begin{array}{l}12 \text { girl, } 6 \text { boy } \\
\text { (Use if broken down } \\
\text { by male and female } \\
\text { experience) }\end{array}$ & $\begin{array}{l}\text { Ethnography, } \\
\text { on location with } \\
\text { the youth }\end{array}$ & $\begin{array}{l}\text { Ottawa, Canada, } \\
2006 \text { to } 2010\end{array}$ \\
\hline $\begin{array}{l}\text { Mann, Senn, } \\
\text { Girard, \& } \\
\text { Ackbar (2007) }\end{array}$ & $\begin{array}{l}\text { Community-based } \\
\text { interventions for } \\
\text { at-risk youth in } \\
\text { Ontario under } \\
\text { Canada's Youth } \\
\text { Criminal Justice Act: } \\
\text { A case study } \\
\text { of a "Runaway" girl }\end{array}$ & $\begin{array}{l}\text { Case study, } \\
\text { Interview }\end{array}$ & 1 girl & 16 years old & $\begin{array}{l}\text { Ontario, Canada, } \\
2006 \text { to } 2008\end{array}$ \\
\hline Martinez (2006) & $\begin{array}{l}\text { Understanding } \\
\text { runaway teens }\end{array}$ & Interviews & $\begin{array}{l}18 \text { girls, } 5 \text { boys } \\
\text { (Use if broken } \\
\text { down by male and } \\
\text { female experience) }\end{array}$ & $\begin{array}{c}13 \text { to } 17 \text { years old } \\
(\mathrm{FM}=14.4) \\
8 \text { Hispanic, } 1 \mathrm{NA}, \\
5 \text { AA, } 3 \text { White, } \\
1 \text { Asian }\end{array}$ & $\begin{array}{c}\text { Midwestern } \\
\text { United States city }\end{array}$ \\
\hline $\begin{array}{c}\text { Peled \& } \\
\text { Cohavi (2009) }\end{array}$ & $\begin{array}{l}\text { The meaning of } \\
\text { running away for girls }\end{array}$ & $\begin{array}{l}\text { Semi-structured, } \\
\text { naturalistic } \\
\text { Interviews }\end{array}$ & 10 girls & $\begin{array}{c}\text { Residential } \\
\text { placements, } \\
13 \text { to } 17 \text { years old }\end{array}$ & Israel \\
\hline $\begin{array}{c}\text { Peled \& } \\
\text { Muzicant (2008) }\end{array}$ & $\begin{array}{l}\text { The meaning } \\
\text { of home for } \\
\text { runaway girls }\end{array}$ & $\begin{array}{l}\text { In-depth } \\
\text { interviews, } \\
\text { naturalistic } \\
\text { qualitative } \\
\text { approach }\end{array}$ & $\begin{array}{l}15 \text { girls } \\
\text { and women }\end{array}$ & $\begin{array}{c}\text { Location of } \\
\text { interviews no } \\
\text { provided, } 13 \text { to } 21 \\
\text { years old }(\mathrm{M}=15.9) \text {, } \\
5 \text { Israeli born, } 4 \text { from } \\
\text { Ethiopia, } 5 \text { from } \\
\text { former Soviet Union }\end{array}$ & $\begin{array}{l}\text { Tel-Aviv, Israel, } \\
\text { dates not provided }\end{array}$ \\
\hline $\begin{array}{c}\text { Wesely \& } \\
\text { Wright (2009) }\end{array}$ & $\begin{array}{l}\text { From the inside out: } \\
\text { Efforts by homeless } \\
\text { women to disrupt cycles } \\
\text { of crime and violence }\end{array}$ & $\begin{array}{l}\text { Qualitative } \\
\text { Interviews }\end{array}$ & 20 women & $\begin{array}{c}2 \text { homeless centers, } \\
19 \text { ton } 64 \text { years old } \\
(\mathrm{M}=40) .6 \mathrm{AA}, \\
3 \text { Hispanic, } 1 \text { mixed } \\
\text { AA/NA, } 1 \text { mixed } \\
\text { Puerto Rican/AA, } \\
9 \text { White }\end{array}$ & $\begin{array}{l}\text { Purposive sampling, } \\
\text { Southeastern } \\
\text { metropolitan area } \\
\text { in the United States, } \\
\text { September } 2003 \text { to } \\
\text { January } 2004\end{array}$ \\
\hline
\end{tabular}




\section{Continued}

\begin{tabular}{|c|c|c|c|c|c|}
\hline $\begin{array}{c}\text { Williams \& } \\
\text { Lindsey (2006) }\end{array}$ & $\begin{array}{l}\text { Spirituality and religion } \\
\text { in the lives of runaway } \\
\text { and homeless youth }\end{array}$ & $\begin{array}{l}\text { Qualitative } \\
\text { Interviews }\end{array}$ & $\begin{array}{c}11 \text { women, } 7 \text { men, } \\
6 \text { AA, } 1 \text { Cuban, } \\
12 \text { Caucasian } \\
\text { (Use if broken down } \\
\text { by male and female } \\
\text { experience) }\end{array}$ & $\begin{array}{l}\text { Shelters, drop } \\
\text { in centers, } \\
18 \text { to } 25 \text { years old }\end{array}$ & $\begin{array}{c}\text { Georgia and } \\
\text { North Carolina, } \\
\text { United States }\end{array}$ \\
\hline $\begin{array}{l}\text { Williams, Lindsey, } \\
\text { Kurtz, \& Jarvis (2001) }\end{array}$ & $\begin{array}{l}\text { From trauma to } \\
\text { resiliency: Lessons from } \\
\text { former runaway and } \\
\text { homeless youth }\end{array}$ & $\begin{array}{l}\text { Qualitative } \\
\text { Interviews }\end{array}$ & $\begin{array}{c}11 \text { women, } 7 \text { men, } \\
6 \text { AA, } 1 \text { Cuban, } \\
12 \text { Caucasian] } \\
\text { (Use if broken down } \\
\text { by male and } \\
\text { female experience) }\end{array}$ & $\begin{array}{l}\text { Shelters, drop } \\
\text { in centers, } \\
18 \text { to } 25 \text { years old }\end{array}$ & $\begin{array}{l}\text { Georgia and } \\
\text { North Carolina, } \\
\text { United States }\end{array}$ \\
\hline
\end{tabular}

Table 2. Theme extraction.

\begin{tabular}{|c|c|}
\hline Study & Themes \\
\hline \multirow{3}{*}{ Berman et al. (2009) } & 1) Displacement and disconnection in dangerous places \\
\hline & 2) Tenuous connections amid spaces of hope \\
\hline & 3) Negotiating spaces of belonging \\
\hline \multirow{15}{*}{ Maassen et al. (2013) } & 1) The homeless teenage need for safety \\
\hline & a) Fears for physical safety \\
\hline & b) Fears for psychological well being \\
\hline & 2) The homeless teenage need to belong \\
\hline & a) Sense of community belonging \\
\hline & b) Bonded through conformity \\
\hline & c) Intimacy \\
\hline & 3) The homeless teenage need for autonomy and self-esteem \\
\hline & a) Regimented routines \\
\hline & b) Strict curfews \\
\hline & c) Rigid rules \\
\hline & 4) The homeless teenage need for self-actualization \\
\hline & a) Identity \\
\hline & b) Individuality \\
\hline & c) Integrity \\
\hline \multirow{5}{*}{ MacDonald (2013) } & 1) Structural constraints that promote a climate of risk taking \\
\hline & a) Social assistance \\
\hline & b) Housing \\
\hline & 2) Survival and identity experimentation \\
\hline & 3) Stigma, power, and complex social representations \\
\hline \multirow{12}{*}{ Mann et al. (2007) } & 1) Initial risk: Family violence \\
\hline & 2) Being kicked out and running away \\
\hline & 3) Youth violence: Rape, rage, retaliation \\
\hline & 4) Youth violence: Escalation \\
\hline & 5) Dangerous/desperate pathways \\
\hline & 6) Youth supports: The police \\
\hline & 7) Youth supports and responsibilizations: Child protection services \\
\hline & 8) Youth supports and responsibilizations: The schools \\
\hline & 9) Youth supports and responsibilizations: Student welfare \\
\hline & 10) Youth supports and advocacy: Counselling services \\
\hline & 11) Youth resources: Connectedness \\
\hline & 12) Youth resources: Identity \\
\hline \multirow{3}{*}{ Martinez (2006) } & 1) Changing the situation \\
\hline & 2) Creating new affiliations \\
\hline & 3) Learning from experience \\
\hline
\end{tabular}




\section{Continued}

\begin{tabular}{|c|c|}
\hline \multirow{8}{*}{ Peled \& Cohavi (2009) } & 1) The home \\
\hline & a) Mother, father, and siblings \\
\hline & b) The extended family \\
\hline & c) The girl \\
\hline & 2) Outside the home \\
\hline & a) School and friends \\
\hline & b) Helping professionals \\
\hline & 3) The moments before \\
\hline \multirow{11}{*}{ Peled \& Muzicant (2008) } & 1) There is a home \\
\hline & a) The ideal home \\
\hline & b) The actual home as a prison \\
\hline & c) The home as a women's prison \\
\hline & d) Extinction of the self \\
\hline & 2) There is no home \\
\hline & a) Homeless in their own home \\
\hline & b) Running away \\
\hline & c) The search for an alternate home \\
\hline & d) Vulnerability and being different \\
\hline & 3) And still there is a home \\
\hline \multirow{3}{*}{ Wesely \& Wright (2009) } & 1) Childhood victimization and lessons learned \\
\hline & 2) Struggling with the cycle of violence \\
\hline & 3) Acts of recognition and resistance \\
\hline \multirow{5}{*}{ Williams \& Lindsey (2006) } & 1) Divine intervention \\
\hline & 2) Personal relationship with God or a higher power \\
\hline & 3) Role of prayer \\
\hline & 4) Participation in traditional and non-traditional religious practices \\
\hline & 5) Finding meaning and purpose in life \\
\hline \multirow{11}{*}{ Williams et al. (2001) } & 1) Determination \\
\hline & 2) Meaning and purpose to life \\
\hline & a) Spiritual connection \\
\hline & b) Hope and gratitude \\
\hline & c) Helping others and giving back \\
\hline & 3) Caring for self \\
\hline & a) Recognizing and meeting own needs \\
\hline & b) Development of effective problem-solving skills \\
\hline & 4) Accepting help from others \\
\hline & a) Readiness for help \\
\hline & b) Quality of help \\
\hline
\end{tabular}

articles. Synthesis of the original themes and subthemes allowed for the creation of new overarching themes that encompassed the narrative each of the articles.

An additional researcher experienced in the QIMS process but not familiar with runaway issues joined the writer for the synthesis of the themes. In doing this, the researcher added triangulation of analysts to the QIMS process. According to Aguirre and Bolton (2014), such triangulation provides a "synergistic understanding" across the studies in the QIMS (p. 11). Triangulation helped to ensure that the theme extraction and the development of new themes remained true to the original studies. Presentation of the new themes also included direct quotations from the participants in the studies, which also helped maintain the integrity of the original studies (Aguirre \& Bolton, 2014). 


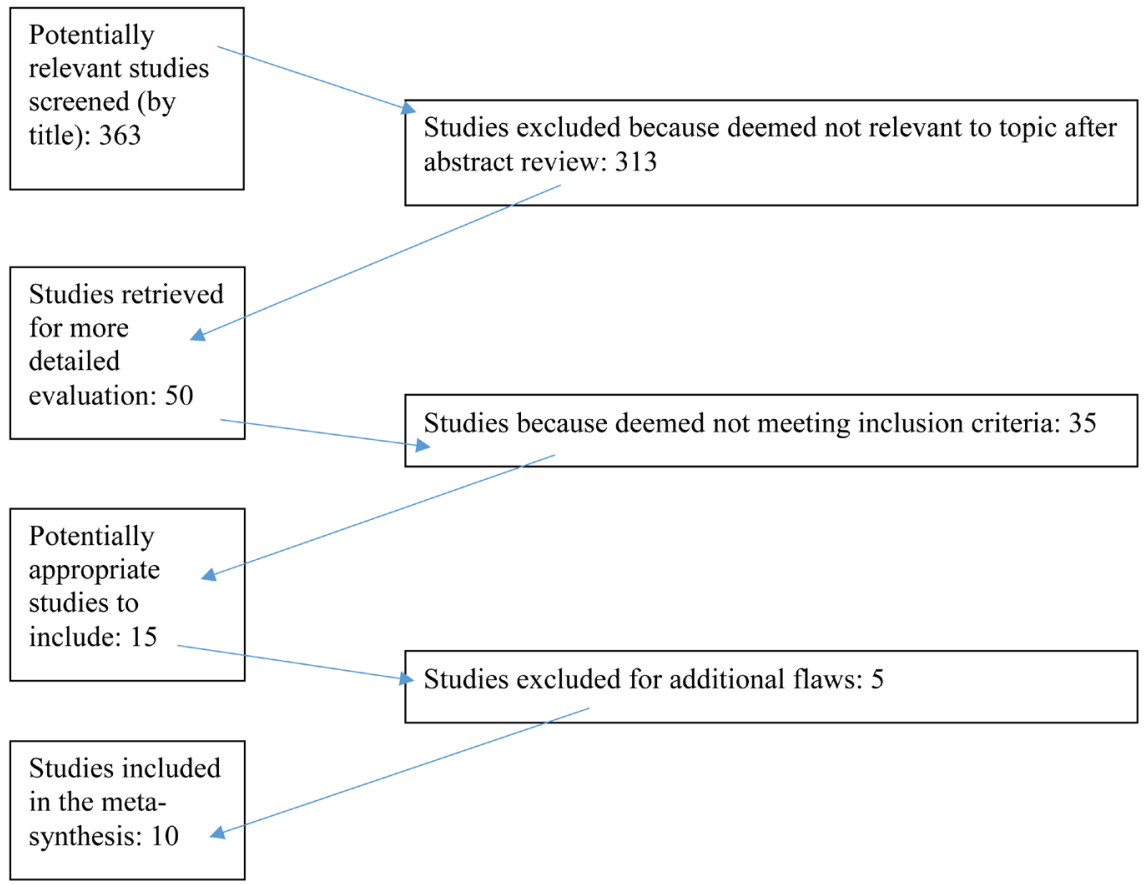

Figure 1. Quorum chart. Adapted from Aguirre \& Bolton (2014).

Patton (2002) suggested additional triangulation in qualitative research, including triangulation of method and theory. Both of these occurred when examining the original studies (see Table 1). Methods varied across the studies including multiple forms on interviewing such as semi-structured, narrative, and naturalistic interviewing. Additionally, one study utilized a case study. Qualitative theories also varied across the studies. Ethnography, phenomenology, narrative, and case study were all used throughout different studies. The triangulation of multiple methods and theoretical qualitative approaches strengthens the studies and this synthesis (Aguirre \& Bolton, 2014; Patton, 2002).

\section{Results}

Analysis of the ten articles resulted in six themes: power and control, stigma, physical needs, safety, belonging, and acceptance (see Table 3). The themes of power/control and stigma are analyzed and presented in a separate article (Crawford, Forthcoming). The themes emerged from the synthesis in a way that mirrored the beginning stages of Maslow's hierarchy of needs. In qualitative research, themes may emerge and then analysis demonstrates how those themes match a theory. In this research, the themes matched Maslow and are presented here through that prism. Presentation and discussion of themes of physical needs, safety, belonging, and acceptance are presented below with accompanying quotations.

\section{Physical needs}

After a youth runs away, meeting her physical needs becomes paramount. When asked about where she considered home, one participant stated, "I'm not really 
Table 3. Results of translation.

\begin{tabular}{|c|c|}
\hline $\begin{array}{c}\text { New, } \\
\text { overarching theme }\end{array}$ & Extracted themes and subthemes with citations \\
\hline Physical needs & $\begin{array}{l}\text { - } \quad \text { The homeless teenage need for safety (Maassen et al., 2013) } \\
\text { - } \quad \text { Survival and identity experimentation (MacDonald, 2013) } \\
\text { - Caring for self: (Williams et al., 2001) }\end{array}$ \\
\hline Safety & $\begin{array}{l}\text { - } \\
\text { - } \quad \text { Tisplacement and disconnection in dangerous places } \\
\text { - } \quad \text { Initial risk: Family violence (Mann et al., 2007) } \\
\text { - } \quad \text { There is a home: Extinction of the self (Peled \& Muzicant, 2008) } \\
\text { - } \quad \text { There is no home: Vulnerability and being different } \\
\text { (Peled \& Muzicant, 2008) } \\
\text { - } \quad \text { Youth violence: Rape, rage, retaliation (Mann et al., 2007) } \\
\text { - } \quad \text { Youth violence: Escalation (Mann et al., 2007) } \\
\text { - } \quad \text { Langerous/desperate pathways (Mann et al., 2007) } \\
\text { - } \quad \text { Childhood victimization and lessons learned } \\
\text { (Wesely \& Wright, 2009) } \\
\text { Struggling with the cycle of violence (Wesely \& Wright, 2009) }\end{array}$ \\
\hline Belonging & $\begin{array}{l}\text { - } \quad \begin{array}{l}\text { Negotiating spaces of belonging (Berman et al., 2009) } \\
\text { - }\end{array} \text { Tenuous connections amid spaces of hope (Berman et al., 2009) } \\
\text { - } \quad \text { Yhe homeless teenage need to belong (Maassen et al., 2013) } \\
\text { - } \quad \text { Creating new affiliations (Martinez, 2006) } \\
\text { - } \quad \text { Outside the home: School and friends and Helping professionals } \\
\text { - } \quad \text { Theled \& Cohavi, 2009) } \\
\text { - } \quad \text { There is no home: Vulnerability and being different } \\
\text { There is a home: The ideal home; The actual home as a prison; } \\
\text { - } \quad \text { The home as a women's prison (Peled \& Muzicant, 2008) } \\
\text { Divine intervention (Williams \& Lindsey, 2006) } \\
\text { Role of prayer (Williams \& Lindsey, 2006) } \\
\text { Participation in traditional and non-traditional religious practices } \\
\text { (Williams \& Lindsey, 2006) } \\
\text { Youth supports and advocacy: Counselling services } \\
\text { (Mann et al., 2007) }\end{array}$ \\
\hline Acceptance & $\begin{array}{l}\text { - The homeless teenage need for self-actualization } \\
\text { (Maassen et al., 2013) } \\
\text { - } \quad \text { Youth resources: Identity (Mann et al., 2007) } \\
\text { The home: Mother, father, and siblings; The extended family; } \\
\text { and The girl (Peled \& Cohavi, 2009) } \\
\text { - } \quad \text { And still there is a home (Peled \& Muzicant, 2008) } \\
\text { - } \quad \text { Personal relationship with God or a higher power } \\
\text { - } \quad \text { Finding meaning and purpose in life (Williams \& Lindsey, 2006) } \\
\text { - } \quad \text { Meaning and purpose to life (Williams et al., 2001) }\end{array}$ \\
\hline
\end{tabular}

sure. Just a place where it's a roof over your head, I don't know" (Berman et al., 2009: p. 423). Other young women recalled their first nights on the streets in detail. One said, "I found it really scary and I was just afraid at night. I remember crying myself to sleep a few times, cuz it was just so scary and I wasn't use [sic] to it" (Maassen et al., 2013: p. 59). Kameka described living on the streets as a "big struggle involving learning not to be a doormat and learning the difference 
between what is abuse and what is not abuse" (Williams et al., 2001: p. 246). Another teen discussed the other people who occupied the streets with her. "Some people here, well some are stable and some are unstable" (Maassen et al., 2013: p. 59).

Lucy summarized the threats to physical needs that are specific to young women living on the streets as it related to her substance use:

Being a young woman, men are always after you for sex, trying to pick you up, offering you loaded needles to sleep with them, or they'll say they'll give you free drugs for a month if you sleep with them. Being a substance user means it's dangerous to get the drugs you need and use them safely (Mac-

Donald, 2013: p. 435).

\section{Safety}

Safety itself was always a concern for the youth in the study. The experience of being a runaway created unsafe situations in many aspects of life for the youth. Tim Garfield explained, "We may put ourselves in situations, but if we get out of it alive, then it's just another experience" (Martinez, 2006: p. 84). The dangers of living on the streets were ever-present. One youth spoke of always being on the move:

I hate moving from one place to another never knowing where you're going to be the next day, never knowing that-especially if you're out actually sleeping on the street and you fall asleep, that's like entrusting the people of the city not to come up and harm you. I am petrified of people (Berman et al., 2009: p. 425).

Substance use was also a safety issue discussed by many of the youth in the studies. Tracey said, “There have been so many times when I've used massive amounts of heroin, massive amounts of cocaine through intravenous use, when there have been times that I should have died" (Williams \& Lindsey, 2006: p. 28). Many of the girls spoke about the dangers inherent for girls who lived on the streets. Connie discussed that prostitution was often the only method of work that young girls had available to them because selling drugs was reserved for the boys who lived on the streets (Mann et al., 2007). Tanya reported, "Girls have a hard time on the street. It's harder for them than for boys, because they're constantly being raped and hurt... it's really dangerous for girls to be on the street" (Peled \& Muzicant, 2008: p. 451). Connie discussed her rape throughout her interview:

I've been raped and everything. Like absolutely everything that could happen has happened basically... And um, so, I remember not believing it happened. I remember pushing it totally out of mind, to the point where I forgot it happened. And then every once in a while I had this creepy feeling like something had happened to me. Something bad had happened to me that I needed help for, and I didn't know what it was. And it doesn't sound, like that sounds crazy (Mann et al., 2007: p. 48). 
In addition to rape, abuse was a common trauma among the girls in the interviews. Tamara recalled, "I had watched [my father] beat my mother with a belt just like he beat us. All my life seeing my father beat my mother with a belt, [and] my sister's abusive husband that raped me and beat me" (Wesely \& Wright, 2009: p. 226). Ruby and Junie both also reported abuse being a common event in their lives from the time they were children extending into relationships they had later in their lives (Wesely \& Wright, 2009). Often the abuse was horrific in detail. From Ruby:

My father used to beat me with belts, sticks; he used to hit me with his work boots. He's pulled a knife on me before. My mother hit me with her hands in the face. My sister scalded me with hot water, and my brother has tried to break my wrists a couple of times (Wesely \& Wright, 2009: p. 222).

Jennifer recounted a story of living with a friend, with whom she had made a pact to stay safe on the streets by one of them remaining sober while the other got high and stripped for money. "At that time, we had like six or seven people who were drug dealers that were coming in and out of the house and the group that I was living in was really bad" (Martinez, 2006: p. 84).

\section{Belonging}

Jennifer's retelling of safety concerns of her living situation rested on another theme in the study - that of belonging. Despite the lack of safety, Jennifer felt she belonged there and this was enough for her to stay. Other participants told similar stories, such as the one who said, "I needed to do everything that everyone else was doing so I could fit in. Other people were doing this and that and I was just totally different. I didn't know who I was at one time" (Maassen et al., 2013: p. 61).

The need to belong often helped the youth forge new "family" from the people with whom they shared experiences. Jade exemplified this by saying, "My mom wasn't there, my dad wasn't there, they (her new family) were there...they've accepted me into their families, and now I have nieces and nephews" (Martinez, 2006: p. 82). This created family was often referred to as street family, defined in the following passage:

A street family is, you know, there's people that I've helped out. Some stay with us once in a while and we help them out. And they don't bring drugs or alcohol into our home. And we're just-you know, they help us out with food or we help them out with whatever. You know, I help people out with cigarettes and just, uh, they help me, you know. We just look out for each other. I just, um-I find that-I mean, I have parents but in many ways I feel like an orphan (Berman et al., 2009, p. 426).

\section{Acceptance}

The street family provided youth the acceptance for which they longed. They reflected this when talking about other adults in their lives who failed to accept them unconditionally. Often, their descriptions harken to other themes discussed 
in these results, including stigma and power. For instance, they discussed being treated like a stereotype and given a set of rules designed for everyone without consideration for the individual's needs (Maassen et al., 2013; Mann, et al., 2007). Another participant summed this up well: Workers "should actually talk to the certain person individually and see what they had, their childhood and treat them individually" (Maassen et al., 2013: p. 64).

The desire for acceptance, though, began at home for most of the girls. Yulia talked about crying when told by someone that they loved her because she had never heard it before (Peled \& Cohavi, 2009). Even while living on the streets, the desire to be accepted by family remained. Hagar discussed living in a hostel: "It's right close to home, I asked to be close to home because home is very important to me. Like, if I lose them, then I'll have nothing" (Peled \& Cohavi, 2008: p. 453).

Acceptance was sometimes found in faith. Trisha discussed negative and positive experiences with churches. "The feeling that I was being judged... this hateful awful God looking down after me, and I didn't want that" (Williams \& Lindsey, 2006: p. 29); however, she later described, "And that [God] has a purpose for me and that he is going to keep me here no matter how many times I try to kill myself" (Williams \& Lindsey, 2006: p. 32).

Acceptance, in the end, was about the girls finding themselves, and accepting that person. Connie described it this way:

And being a true person to myself 'cause I understand who I am. I know who I am. I'm 16 years old and I can tell you, I know who I am and that's awesome. Because I know a lot of people can't tell you that when they're 30. So I'm, I, I'm, I don't know. I feel like at the same time, I wouldn't want it any bet, any different, because I've learned so much and I've matured so much and I'm so much stronger. So confidence in myself (Mann et al., 2007: pp. 61-62).

\section{Discussion}

Discussion of the themes will focus analysis through the prism of Maslow's (1954) hierarchy of needs. The hierarchy of needs creates a pyramid of needs going from bottom to top for individuals to meet throughout their lives (Maslow, 1954). Implications for helping professionals are woven throughout the discussion.

\section{Physical Needs}

The hierarchy rests on the basic physiological needs such as shelter, food, water, sex, and sleep (Maslow, 1954). After the girls ran away, they were first concerned with meeting this basic need. They discussed the need to put a roof over their heads and making sure they could eat. Trisha recalled realizing that she had to put her needs as number one now because no one else was going to (Williams et al., 2001). Helping professionals often assist in meeting basic physical needs. Facilities are available in many cities where homeless adults and youth can go to meet their need for shelter. Food pantries and other charities attempt to meet the 
need of hunger for people living on the streets. As demonstrated above, however, often these facilities have regulations that lead youth to choose not to stay. Professionals should be aware of these barriers and assist youth in finding appropriate shelter.

Harm reduction models rely on finding alternatives that may not appear to be the best choice, but meet the immediate needs and have less harm than other choices that may be available to the client (Brocato \& Wagner, 2003). Models such as this have had success in studies (see: Ward \& Fortune, 2006; Wright et al., 2012). Connie stated she was repeatedly taken home because the professionals thought this was the best place for her; she felt her voice was not heard (Mann et al., 2007). By listening to Connie, a helper may have found a solution that met Connie's immediate needs while keeping her off of the streets.

\section{Safety}

Maslow (1954) posited that once an individual has basic physiological needs met, the individual assesses safety. The hierarchy builds from one level up to the next; however, people may go back and forth between different levels because of their circumstances (Maslow, 1954). For instance, Lucy's description of meeting physical needs by trading drugs or sex also created safety concerns for her (MacDonald, 2013). She recognized that as a female living on the streets, she had to be cognizant of the threat of rape or sexual violence all while meeting her needs (MacDonald, 2013).

Threats against their safety can cause the young women to remain on guard all of the time. This triggers an innate fight or flights response that causes maladaptive behaviors when it cannot shut off (Perry et al., 1995). A participant in Berman et al. (2009) spoke of the fear of falling asleep because of the harm that may come to her from anyone passing by. While many people may find this fear exhausting, Tim Garfield's explanation that the fear becomes a lived experience that they get through everyday demonstrates how it is normalized in their lives (Martinez, 2006). Violence and trauma were common to the point of being normal to the girls in the studies. Nearly every study had a participant who mentioned domestic violence or sexual trauma in their past before running away or after living on the streets. Hayley, Ruby, Junie, and Marion all discussed ways that they recognized the cycle of violence in their lives from their childhoods to their young adult lives to the lives of their own children (Wesely \& Wright, 2009).

The constant threat against their safety created an atmosphere is distrust. The participants discussed not trusting most people, often even those with whom they were living. One said she had learned never to make friends because even they cannot be trusted (Berman et al., 2009). When describing people she has lived within the past, one participant said, "Some of them are a bit psycho" (Maassen et al., 2013: p. 59).

Within these constraints, helping professionals must adapt to meet the needs of the girls. Having been on the streets and involved with multiple social service systems, many of the girls are systems-savvy. Professionals should recognize this 
a strength (and not manipulation) and build from it (Shdaimah \& Leon, 2014). An important step in this process is giving the girls the power to create an image of safety for themselves, even if this image is not the one that the social worker would have constructed. In doing this, the client is empowered and builds trust. This atmosphere is essential in building the next step in Maslow's hierarchythat of belonging.

\section{Belonging}

Maslow (1954) wrote that belonging comes after an individual meets her physiological and safety needs. Belonging refers to the creation of important relationships such as friends and family. While Maslow (1954) constructed this level as being attained after the first two were reached, for many in the study, belonging was a means to achieving physiological and safety needs. One participant spoke of doing what she needed to in order to stay where she had shelter, while another spoke the importance of having a relationship with someone so she would know that she always had another person there for her (Maassen et al., 2013).

Girls in the study discussed the creation of family through important friendships and relationships they had created on the streets. This met their need for belonging. Other studies have demonstrated this as well. Crawford, grant, and Crews (2016) wrote that young men in their study created new families from their peer group because they felt the group was comprised of the only people they could trust. When a participant in Berman et al. (2009) spoke about street family, this is what she referred to-a group of people with whom she created a trusting and lasting relationship on whom she could always rely.

Helping professionals should seek to build on these relationships. In many ways, this may build upon the notion of harm reduction practices again. While the relationships may not represent the ideal family or have a blood relationship, the girls are meeting needs through them. Helping professionals should assess the safety of the situation to ensure basic needs and safety are met, and then work to reduce harm wherever possible. Sometimes, this may mean working with the street family of the youth to ensure she is safe and her needs are met.

\section{Acceptance}

Maslow (1954) called the acceptance level esteem, referring to the individual's confidence, esteem, and respect. As the participants in the studies discussed acceptance, they often did so in the terms that Maslow used to describe the esteem level. Previous levels in the hierarchy should be achieved before reaching this level, although movement between the levels is possible as situations fluctuate (Maslow, 1954).

Connie discussed that she did not want to be known as a "thug" or a "punk" (Mann et al., 2007: p. 61). She discussed how she used to feel down on herself when she was rejected, but now she knew she was a good person and did not deserve to be treated that way (Mann et al., 2007). Several of the girls discussed that they just wanted to be respected by workers and by other professionals who were involved in their lives (Maassen et al, 2013; Martinez, 2006; Williams \& Lindsey, 2006). 
Professionals can assist with meeting this need. Ultimately, though, acceptance is about the girls accepting themselves. Some had a plan developed to do this. Connie discussed having a family and treating them the way she never was treated (Mann et al., 2007). Hayley had accepted the negative things in her past and vowed to move forward, creating a different life for herself (Wesely \& Wright, 2009). Accepting her sexual minority status was empowering for Trisha (Williams et al., 2001). In each of these experiences, helping professionals can play a pivotal role to ensure that the girls find the acceptance that they need.

\section{Conclusion}

This study revealed the myriad concerns that girls face when they run away from home. In many ways, helping professionals are aware of most of these concerns. One should not be surprised that living on the streets is unsafe for teenage girls. Maslow presented his Hierarchy of Needs over half a century ago. The relevance of the model is demonstrated by the analysis of these studies, showing that runaway youth often seek to meet the initial stages of hierarchy before being able to move to higher levels. Helping professionals should be aware of these levels as they work with youth living on the streets. Meeting clients where they are may mean assessing what level of the hierarchy the youth is currently in and assisting meeting the needs of that level even if other concerns exist. These types of harm reduction models seek to improve conditions while minimizing risks. While helpers are often involved in meeting the needs of runaway youth, they should be cognizant of the concerns that were revealed in this study before they take a onesize-fits-all approach to their work. More times than may be realized, the girls may have the answer all along. Williams et al. (2001) summarized it well with this quotation from Sally: "I can do just about anything if I put my mind to it" (p. 242). The helping professional's job sometimes is simply to clear the path.

\section{Conflicts of Interest}

The author declares no conflicts of interest regarding the publication of this paper.

\section{References}

Aguirre, R., \& Bolton, K. (2013). Why Do They Do It? A Qualitative Interpretive MetaSynthesis of Crisis Volunteers' Motivations. Social Work Research, 37, 327-338. https://doi.org/10.1093/swr/svt035

Aguirre, R., \& Bolton, K. (2014). A Qualitative Interpretive Meta-Synthesis in Social Work Research: Uncharted Territory. Journal of Social Work, 14, 279-294. https://doi.org/10.1177/1468017313476797

Berman, H., Mulcahy, G., Forchuk, C., Edmunds, K., Haldenby, A., \& Lopez, R. (2009). Uprooted and Displaced: A Critical Narrative Study of Homeless, Aboriginal, and Newcomer Girls in Canada. Issues in Mental Health Nursing, 30, 418-430. https://doi.org/10.1080/01612840802624475

Bowers, P. (2013). Community Based Participatory Research and Youth Tobacco Control: A Qualitative Interpretive Meta-Synthesis. Perspectives on Social Work, 9, 58. 
Brocato, J., \& Wagner, E. (2003). Harm Reduction: A Social Work Practice Model and Social Justice Agenda. Health \& Social Work, 28, 117-125.

https://doi.org/10.1093/hsw/28.2.117

Cochran, B., Stewart, A., Ginzler, J., \& Cauce, A. M. (2002). Challenges Faced by Homeless Sexual Minorities: Comparison of Gay, Lesbian, Bisexual, and Transgender Homeless Adolescents with Their Heterosexual Counterparts. American Journal of Public Health, 92, 773-777. https://doi.org/10.2105/AJPH.92.5.773

Crawford, M. (Forthcoming). What Would Foucault Say? Applying the Theoretical Lens of Power/Control and Stigma through a Qualitative Interpretive Meta-Synthesis of Runaway Girls.

Crawford, M., Grant, N., \& Crews, D. (2016). Relationships and Rap: Using Ecomaps to Explore the Stories of Youth Who Rap. British Journal of Social Work, 46, 239-256.

Fasulo, S., Cross, T., Mosely, P., \& Leavey, J. (2002). Adolescent Runaway Behavior in Specialized Foster Care. Children and Youth Services Review, 24, 623-640. https://doi.org/10.1016/S0190-7409(02)00211-6

Frank, L., \& Aguirre, R. (2013). Suicide in the Prisons: A Qualitative Interpretive Meta-Synthesis. Journal of Sociology and Social Welfare, 40, 31-52.

Haas, A. P., Eliason, M., Mays, V. M., Mathy, R. M., Cochran, S. D., D’Augelli, A. R., Clayton, P. J. et al. (2011). Suicide and Suicide Risk in Lesbian, Gay, Bisexual, and Transgender Populations: Review and Recommendations. Journal of Homosexuality, 58, 10-51. https://doi.org/10.1080/00918369.2011.534038

Hong, J. S., Espelage, D., \& Kral, M. (2011). Understanding Suicide among Sexual Minority Youth in America: An Ecological Systems Analysis. Journal of Adolescence, 34, 885894. https://doi.org/10.1016/j.adolescence.2011.01.002

Hyde, J. (2005). From Home to Street: Understanding Young People's Transitions into Homelessness: Homeless and Runaway Youth. Journal of Adolescence, 28, 171-183. https://doi.org/10.1016/j.adolescence.2005.02.001

Kidd, S., \& Carroll, M. (2007). Coping and Suicidality among Homeless Youth. Journal of Adolescence, 30, 283-296. https://doi.org/10.1016/j.adolescence.2006.03.002

Kurtz, D., Lindsey, E., Jarvis, S., \& Nackerud, L. (2000). How Runaway and Homeless Youth Navigate Troubled Waters: The Role of Formal and Informal Helpers. Child \& Adolescent Social Work Journal, 17, 381-402.

https://doi.org/10.1023/A:1007507131236

Lin, C. H. (2012). Children Who Run Away from Foster Care: Who Are the Children and What Are the Risk Factors? Children and Youth Services Review, 34, 807-813. https://doi.org/10.1016/j.childyouth.2012.01.009

Maassen, K., Pooley, J., \& Taylor, M. (2013). "You Get Forced to Live with Randoms ... and That Makes You Stronger as a Person": Homeless Western Australian Teenagers' Perspectives on Their Experiences of Residing in Crisis Accommodation. The Australian Community Psychologist, 25, 53-73.

Macdonald, S. (2013). The Paradox of Being Young and Homesless: Resiliency in the Face of Constraints. International Journal of Child, Youth and Family Studies, 4, 425-446. https://doi.org/10.18357/ijcyfs44201312695

Maleku, A., \& Aguirre, R. (2014). Culturally Competent Health Care from the Immigrant Lens: A Qualitative Interpretive Meta-Synthesis (QIMS). Social Work in Public Health, 29, 561-580. https://doi.org/10.1080/19371918.2014.893417

Mann, R., Senn, C., Girard, A., \& Ackbar, S. (2007). Community-Based Interventions for At-Risk Youth in Ontario under Canada's Youth Criminal Justice Act: A Case Study of 
a "Runaway" Girl. Canadian Journal of Criminology and Criminal Justice, 49, 37-74. https://doi.org/10.3138/K622-844X-3411-42H1

Martinez, R. (2006). Understanding Runaway Teens. Journal of Child and Adolescent Psychiatric Nursing, 19, 77-88. https://doi.org/10.1111/j.1744-6171.2006.00049.x

Maslow, A. (1943). A Theory of Human Motivation. Psychological Review, 50, 370-396. https://doi.org/10.1037/h0054346

Maslow, A. (1954). Motivation and Personality. Harper and Row.

Meltzer, H., Ford, T., Bebbington, P., \& Vostanis, P. (2012). Children Who Run Away from Home: Risks for Suicidal Behavior and Substance Misuse. The Journal of Adolescent Health, 51, 415-421. https://doi.org/10.1016/j.jadohealth.2012.04.002

Mendez, L. M. R., \& Randle, C. A. (2021). Lifted: A Thematic Analysis of Homeless Adolescents' Reflections on Their Lives since Beginning a Multifaceted, Community-Based Intervention. Children and Youth Services Review, 121, Article ID: 105891.

https://doi.org/10.1016/j.childyouth.2020.105891

Moskowitz, A., Stein, J., \& Lightfoot, M. (2013). The Mediating Roles of Stress and Maladaptive Behaviors on Self-Harm and Suicide Attempts among Runaway and Homeless Youth. Journal of Youth and Adolescence, 42, 1015-1027. https://doi.org/10.1007/s10964-012-9793-4

National Center for Homeless Education [NCHE] (2020). McKinney-Vento Awareness Materials. https://nche.ed.gov

Nebbitt, V., House, L., Thompson, S., \& Pollio, D. (2006). Successful Transitions of Runaway/Homeless Youth from Shelter Care. Journal of Child and Family Studies, 16, 545555. https://doi.org/10.1007/s10826-006-9105-2

Nordberg, A., Crawford, M., Praetorius, R. T., \& Hatcher, S. S. (2016). Exploring Minority Youths' Police Encounters: A Qualitative Interpretive Meta-Synthesis. Child \& Adolescent Social Work Journal, 21, 9-12. https://doi.org/10.1007/s10560-015-0415-3

Patton, M. (2002). Qualitative Research and Evaluation Methods (3rd ed.). Sage Publications, Inc.

Peled, E., \& Cohavi, A. (2009). The Meaning of Running Away for Girls. Child Abuse \& Neglect, 33, 739-749. https://doi.org/10.1016/j.chiabu.2007.04.018

Peled, E., \& Komem, M. (2020). “A Girl's Places in the Home”: Spatial Gendered Scripts in Narratives of Girls Who Have Left or Been Pushed out of Home. Child \& Family Social Work, 25, 240-247. https://doi.org/10.1111/cfs.12679

Peled, E., \& Muzicant, A. (2008). The Meaning of Home for Runaway Girls. Journal of Community Psychology, 36, 434-451. https://doi.org/10.1002/jcop.20222

Perry, B., Pollard, R., Blaicley, T., Baker, W., \& Vigilante, D. (1995). Childhood Trauma, the Neurobiology of Adaptation, and "Use-Dependent" Development of the Brain: How “States” Become “Traits”. Infant Mental Health Journal, 16, 271-291. https://doi.org/10.1002/1097-0355(199524)16:4<271::AID-IMHJ2280160404>3.0.CO;2-B

Pierce, S., Grady, B., \& Holtzen, H. (2018). Daybreak in Dayton: Assessing Characteristics and Outcomes of Previously Homeless Youth Living in Transitional Housing. Children and Youth Services Review, 88, 249-256.

https://doi.org/10.1016/j.childyouth.2018.03.021

Robinson, S., Maxwell, D., \& Rogers, K. (2020). Living in Intimate Partner Violence Shelters: A Qualitative Interpretive Meta-Synthesis of Women's Experiences. The British Journal of Social Work, 50, 81-100. https://doi.org/10.1093/bjsw/bcz079

Roy, E., Haley, N., Leclerc, P., Sochanski, B., Boudreau, J., \& Boivin, J. (2014). Mortality in a Cohort of Street Youth in Montreal. Journal of the American Medical Association, 292, 
569-574. https://doi.org/10.1001/jama.292.5.569

Shdaimah, C., \& Leon, C. (2014). "First and Foremost, They're Survivors": Selective Manipulation, Resilience, and Assertion among Prostitute Women. Feminist Criminology, 10, 326-347. https://doi.org/10.1177/1557085114553832

Thompson, S., Bender, K., Lewis, C., \& Watkins, R. (2008). Runaway and Pregnant: Risk Factors Associated with Pregnancy in a National Sample of Runaway/Homeless Female Adolescents. The Journal of Adolescent Health, 43, 125-132. https://doi.org/10.1016/j.jadohealth.2007.12.015

Tyler, K., Whitbeck, L., Hoyt, D., \& Cauce, A. (2004). Risk Factors for Sexual Victimization among Male and Female Homeless and Runaway Youth. Journal of Interpersonal Violence, 19, 503-520. https://doi.org/10.1177/0886260504262961

Tyler, K., Whitbeck, L., Hoyt, D., \& Johnson, K. (2003). Self-Mutilation and Homeless Youth: The Role of Family Abuse, Street Experiences, and Mental Disorders. Journal of Research on Adolescence, 13, 457-474. https://doi.org/10.1046/j.1532-7795.2003.01304003.x

Unger, J., Kipke, M., Simon, T., Johnson, C., Montgomery, S., \& Iverson, E. (1998). Stress, Coping, and Social Support among Homeless Youth. Journal of Adolescent Research, 13, 134-157. https://doi.org/10.1177/0743554898132003

Walls, N. E., Potter, C., \& Van Leeuwen, J. (2009). Where Risks and Protective Factors Operate Differently: Homeless Sexual Minority Youth and Suicide Attempts. Child and Adolescent Social Work Journal, 26, 235-257. https://doi.org/10.1007/s10560-009-0172-2

Ward, T., \& Fortune, C. (2006). The Good Lives Model: Aligning Risk Reduction with Promoting Offenders' Personal Goals. European Journal of Probation, 5, 29-46. https://doi.org/10.1177/206622031300500203

Wesely, J., \& Wright, J. (2009). From the inside out: Efforts by Homeless Women to Disrupt Cycles of Crime and Violence. Women \& Criminal Justice, 19, 217-234. https://doi.org/10.1080/08974450903001552

Whitbeck, L., Hoyt, D., \& Ackley, K. (1997). Families of Homeless and Runaway Adolescents: A Comparison of Parent/Caretaker and Adolescent Perspectives on Parenting, Family Violence, and Adolescent Conduct. Child Abuse \& Neglect, 21, 517-528. https://doi.org/10.1016/S0145-2134(97)00010-0

Whitbeck, L., Hoyt, D., \& Bao, W.-N. (2000). Depressive Symptoms and Co-Occurring Depressive Symptoms, Substance Abuse, and Conduct Problems among Runaway and Homeless Adolescents. Child Development, 71, 721-732. https://doi.org/10.1111/1467-8624.00181

Williams, N. R., \& Lindsey, E. (2006). Spirituality and Religion in the Lives of Runaway and Homeless Youth. Journal of Religion \& Spirituality in Social Work: Social Thought, 24, 19-38. https://doi.org/10.1300/J377v24n04 03

Williams, N., Lindsey, E., Kurtz, D., \& Jarvis, S. (2001). From Trauma to Resiliency: Lessons from Former Runaway and Homeless Youth. Journal of Youth Studies, 4, 233-253. https://doi.org/10.1080/13676260123589

Woods, J. B. (2018). Unaccompanied Youth and Private-Public Order Failures. Iowa Law Review, 103, 1639-1709.

Wright, T., Schuetter, R., Fombonne, E., Stephenson, J., \& Haning, W. (2012). Implementation and Evaluation of a Harm-Reduction Model for Clinical Care of Substance Using Pregnant Women. Harm Reduction Journal, 9, 5.

https://doi.org/10.1186/1477-7517-9-5 